DOI https://doi.org/10.30525/978-9934-588-81-5-1.9

\title{
СУЧАСНІ АСПЕКТИ КОМПЛЕКСНОЇ ТЕРАПІЇ ХВОРИХ НА ПОШИРЕНИЙ ПСОРІАЗ
}

\author{
Брюханова Т. 0. \\ кандидат біологічних наук, \\ асистент кафедри біологічної хімії \\ Національний фармачевтичний університет \\ Галузінська Л. В. \\ кандидат фармачевтичних наук, \\ доцент кафедри біологічної хімії \\ Національний фармацевтичний університет \\ м. Харків, Украӥна
}

Псоріаз (чешуйчатий лишай) є одним із найбільш розповсюджених захворювань шкіри, що відноситься до хронічних, часто рецидивуючих мультифакторних дерматозів і характеризується запаленням дерми, порушенням кератинізації з гіперпроліферацією епідермальних клітин, а також ураженням нігтів, суглобів і волосистої ділянки голови. За статистичними даними різних авторів, на це захворювання страждає близько 3-4\% населення планети [1-2]. Незважаючи на широке розповсюдження псоріазу і численні дослідження цієї проблеми, на теперішній час не існує однозначної думки щодо його патогенезу. Переважна більшість дослідників вирішальну роль у механізмах розвитку псоріазу віддає спадковій схильності [2-3], а серед провокуючих факторів - травматичним, фізичним, хімічним, біологічним, інфекційним чинникам, неадаптованому метаболічному харчуванню, емоційному і психогенному стресу [1-3]. На думку інших авторів, у патогенезі псоріазу провідну роль відіграють нейроендокринні порушення, хронічний прозапальний стан і патології внутрішніх органів, що супроводжуються ендогенною інтоксикацією, розладами імунітету [23]. Останнім часом все більше уваги приділяється метаболічним порушенням за псоріазу [1-3]. Проте відсутність полісистемної оцінки структурно-метаболічних механізмів формування псоріазу та результатів взаємодії інтегративних ланцюгів забезпечення гомеостазу в кореляції з клінічними проявами хвороби свідчить про необхідність вивчення і уточнення багатьох аспектів даної проблеми, на основі оцінки індикаторних показників обміну речовин та стану інтегративних систем. 
Результати наших попередніх досліджень свідчать про системні порушення метаболічних процесів у хворих на розповсюджений псоpiaз [4]. Ці зміни стосувались усіх видів обміну речовин, що базувались на ендогенній інтоксикація, мітохондріальній дисфункції і порушеннях взаємодії інтегративних систем (нервової, ендокринної, імунної) на тлі активації вільнорадикальних процесів.

В основу запропонованого способу медикаментозної кореції псоріазу покладено задачу підвищення ефективності терапії хворих на поширений псоріаз в прогресуючій стадії шляхом призначення додаткових засобів, що корегують метаболічні процеси, мітохондріальну дисфункцію та проявляють мембранопротекторну активність, стимулюють біоенергетичні процеси. Для обгрунтування ефективності лікування хворих на псоріаз з використанням амінокислотного та коензимного комплексу «Кардонат» було сформовано три групи пацієнтів: у першій групі проводилась загальна місцева терапія 3 включенням «Кардонату»; у другій групі проводилась традиційна схема лікування (системна і місцева терапія); у третій групі проводилось лікування за традиційною методикою, доповненою «Кардонатом». Ефективність лікування оцінювалась за результатами дослідження у динаміці (до і після лікування) імунологічних, біохімічних і клінічних показників. Дослідження показали, що у пацієнтів першої групи залишалися без змін показники вмісту в сироватці крові ендотеліну-1, FASx, СД19, СД4. Загальні Т-лімфоцити (СД3 $\left.{ }^{3}\right)$ вірогідно знижувалися на $87 \%$ після лікування. Застосування у другій групі традиційної терапії супроводжувалось зниженням рівня СД4, ендотеліну-1 і підвищенням СД19. Інші показники не змінювались після проведеної терапії. У третій групі хворих з поширеним псоріазом відмічалось деяке зниження Т-цитотоксичних клітин (СД8), з боку інших показників вірогідних відмінностей не виявлено.

Показники гуморального імунітету у першій групі хворих після лікування не змінювались. У другій групі хворих відмічалось зниження вмісту загальних імуноглобулінів Е, тоді як вміст імуноглобулінів $\mathrm{G}$, M, А у процесі терапії не змінювався. Комплексна терапія з використанням амінокислотного коензимного препарату «Кардонат» в третій групі хворих супроводжувалась ще більш високим рівнем падіння у сироватці імуноглобулінів Е. Змін серед імуноглобулінів М, G, А після лікування не відмічалось. Аналіз показників клітинного і гуморального імунітету свідчив, що в процесі лікування хворих у деякій мірі знижувалась реактивність імунної системи, що обумовлювало формування ендотеліальної дисфункції мікроциркуляторного судинного русла. Особливо це було помітно при лікуванні третьої групи 
хворих, значне зниження рівня імуноглобулінів Е вказує на пригнічення маніфестації аутоімунних процесів та ефективність метаболітно-адаптованого комплексного лікування хворих цієї групи, про що свідчить тривалість перебування хворих пацієнтів у стаціонарі. Середня тривалість перебування пацієнтів першої групи на лікарняному ліжку становила 28 ліжко-днів, другої - 25 ліжко-днів і третьої 20 ліжко-днів.

Вивчення ефективності лікування хворих здійснювалося за динамікою змін моніторингових метаболічних показників: АсТ, АлТ, $\gamma$-ГТ, ЛФ, ЛДГ, КФК, КФК-МВ, білірубіну, креатиніну, сечовини, загального білка, глюкози, альбуміну, холестерину, ТАГ, фосфоліпідів, $\mathrm{Ca}^{2+}$, $\mathrm{Mg}^{2+}, \mathrm{Fe}^{2+}$, фосфору, Ефективність лікування хворих оцінювалась по відношенню до традиційної схеми лікування. Результати дослідження показали, що додаткове призначення до традиційної схеми амінокислотного коензимного комплексу «Кардонат» у хворих на поширений псоріаз в прогресуючій стадії скорочувало термін наступу ремісії і сприяло нормалізації моніторингових метаболічних показників. Високоінформативними моніторинговими показниками оцінки ефективності лікування хворих на поширений псоріаз є сечовина, креатинін, загальний білок, КФК-МВ, $\mathrm{Ca}^{2+}, \mathrm{Mg}^{2+}, \mathrm{Na}^{+}, \mathrm{K}^{+}, \mathrm{Cu}^{2+}, \mathrm{Zn}^{2+}$ і фосфор. Ефективність запропонованого засобу терапії хворих на поширений псоріаз підтверджується даними скорочення перебігу прогресивної та стаціонарної стадії на 5-8 діб і настанням клінічної ремісії.

\section{Література:}

1. Jason E., Hawkes M.D., Tom C., Chan M.D., James G., Krueger M.D. Psoriasis pathogenesis and the development of novel targeted immune therapies. Journal of Allergy and Clinical Immunology. 2017, Volume 140, Issue 3, P. 645-653

2. Kim W. B., Jerome D., Yeung J. Diagnosis and management of psoriasis. Canadian Family Physician. 2017. Vol. 63. №. 4. P. 278-285.

3. Michalek I. M., Loring B., John S. M. A systematic review of worldwide epidemiology of psoriasis . Journal of the European Academy of Dermatology and Venereology. 2017. Vol. 31. №. 2. P. 205-212.

4. Біловол А.М., Солошенко Е. М., Жукова Н.В. Галузінська Л.В., Стеценко С.О., Берегова А.А., Васильєв І.М., Ткаченко С.Г. Патогенетична терапія хворих на розповсюджений псоріаз із урахуванням корекції метаболічних показників (Експериментально-клінічні дослідження). Харків, 2016. 209 с. 